\title{
Zmiany w zakresie przenoszenia przez Radę Ministrów wydatków budżetu państwa w związku z koniecznością przeciwdziałania skutkom COVID-19
}

\author{
Changes in the field of transferring state budget expenditure by the Council \\ of Ministers due to the need to counteract the effects of COVID-19 \\ Изменения, касающиеся перераспределения Советом министров расходов \\ государственного бюджета в связи с необходимостью противодействия \\ последствиям COVID-19
}

\author{
MICHALINA DUDA-HYZ \\ Dr hab., Katolicki Uniwersytet Lubelski Jana Pawła II \\ e-mail: dudami@kul.lublin.pl, https://orcid.org/0000-0001-7058-3481
}

\begin{abstract}
Streszczenie: $W$ artykule przedstawiono i poddano analizie zmiany w zakresie przepisów dotyczących dokonywania przez Radę Ministrów przeniesień wydatków budżetowych, które zostały wprowadzone w związku z koniecznością przeciwdziałania skutkom COVID-19. W pierwszej części opracowania omówiono regulację upoważniającą do zastosowania tego instrumentu w przypadku ogłoszenia stanu zagrożenia epidemicznego albo stanu epidemii. W drugiej zaś analizie poddano przepisy dotyczące przenoszenia wydatków budżetowych w przypadku uruchomienia programu mobilizacji gospodarki. Badania prowadzą do konkluzji, iż wprowadzone zmiany w znaczący sposób poszerzają zakres luzu decyzyjnego egzekutywy w sferze wykonywania budżetu państwa, co może rodzić wątpliwości w świetle konstytucyjnej zasady wyłączności władzy ustawodawczej w kształtowaniu dochodów i wydatków państwa.
\end{abstract}

Słowa kluczowe: budżet państwa, wykonywanie budżetu państwa, przenoszenie wydatków budżetowych, stan zagrożenia epidemicznego, stan epidemii, program mobilizacji gospodarki

Summary: In the article, the changes in the provisions governing the transfer of budget expenditure that were introduced into the Polish legal system in connection with the need to counteract the effects of COVID-19 were presented and analysed. The first part of the paper presents the regulations enabling use of this instrument in case of the declaration of a state of epidemic threat or state of an epidemic. In the second part, the provision enabling the transfer of budget expenditure in the case of launching the Economy Mobilization Program was analysed. The research leads to the conclusion that the introduced changes significantly broaden the scope of the executive's decision-making slack in the implementation of the state budget, which may raise doubts in the light of the constitutional principle of exclusivity of the legislative authority in shaping state revenues and expenditures.

Key words: state budget, implementation of state budget, transfer of budget expenditure, state of epidemic threat, state of epidemic, Economy Mobilization Program

Резюме: В статье представлены и проанализированы изменения в положениях о перераспределении расходов бюджета Советом министров, которые были введены в связи с необходимостью противодействия последствиям COVID-19. В первой части исследования рассматривается регулирование, разрешающее применение этого инструмента в случае введения чрезвычайного положения эпидемической угрозы или чрезвычайного положения эпидемии. Во второй части статьи анализируются положения, касающиеся перераспределения бюджетных расходов в случае запуска программы мобилизации экономики. Исследование приводит к выводу, что внесенные изменения значительно расширяют сферу 
свободы принятия решений исполнительной властью в области исполнения государственного бюджета, что может вызвать сомнения в свете конституционного принципа исключительной роли законодательной власти в формировании государственных доходов и расходов.

Ключевые слова: государственный бюджет, исполнение государственного бюджета, перераспределение бюджетных расходов, чрезвычайное положение эпидемической угрозы, чрезвычайное положение эпидемии, программа мобилизации экономички

\section{Wstęp}

Instytucja przeniesień wydatków budżetowych stanowi stały instrument gospodarki budżetowej służący umożliwieniu dokonywania zmian w toku wykonywania budżetu bez konieczności nowelizacji ustawy budżetowej. Potrzeba dokonania przeniesień może stanowić konsekwencję błędów na etapie planowania budżetu, pojawienia się oszczędności w określonych podziałkach klasyfikacji budżetowej, czy też wynikać z przyczyn obiektywnych, związanych z zaistnieniem nieprzewidzianych zdarzeń w sferze życia społecznego, gospodarczego lub politycznego. Zjawisko pandemii oraz jego skutki społeczno-ekonomiczne niewątpliwie należą do tego rodzaju obiektywnych okoliczności. Niemniej należy podkreślić, że instrument przenoszenia wydatków budżetowych, wywołujący skutek w postaci modyfikacji określonych w treści ustawy budżetowej zakresów upoważnień budżetowych do dokonywania wydatków ${ }^{1}$, jest stosowany przez organy egzekutywy. Pod rządami Konstytucji Rzeczypospolitej Polskiej, w świetle której uchwalanie budżetu w formie ustawy realizuje w płaszczyźnie finansowej zasadę podziału władz ${ }^{2}$, stosunek do tej instytucji nie powinien być zatem liberalny ${ }^{3}$. Przyznanie zbyt szeroko zakrojonych uprawnień w rzeczonej sferze stwarza bowiem zagrożenie zmniejszenia kontroli parlamentu nad wydatkami państwa ${ }^{4}$. Powyższa teza znajduje dodatkowe

1 Termin „upoważnienie budżetowe do dokonania wydatku” przyjęty za T. Dębowska-Romanowska, Charakter $i$ klasyfikacja tzw. wydatków sztywnych a granice swobody politycznej władz państwa, w: Uwarunkowania i bariery w procesie naprawy finansów publicznych, red. J. Głuchowski, A. Pomorska, J. Szołno-Koguc, Lublin 2007, s. 283. W doktrynie prawa finansowego wskazuje się, że przeniesienia wydatków powodują, że ma miejsce przesuwanie uprawnień do dokonywania wydatków w stosunku do uprawnień przyznanych w pierwotnym brzmieniu ustawy budżetowej. Zob. A. Borodo, Konstrukcja prawna ustawy budżetowej, Toruń 2017, s. 140.

2 Zob. B. Banaszak, Konstytucja Rzeczypospolitej Polskiej. Komentarz, Warszawa 2012, s. 1059.

3 Wyrazem liberalnego stosunku do tej instytucji byłoby przyznanie prawa do przenoszenia wydatków w szerokim zakresie wykonawcom budżetu, w tym wykonawcom bezpośrednim. Por. L. Kurowski, Wstęp do nauki prawa finansowego, Warszawa 1976, s. 103-104.

4 Zob. K.M. Stepaniuk, Zagadnienie zmian $w$ wydatkach budżetu państwa $w$ trakcie jego realizacji w świetle ustawy o finansach publicznych, w: Finanse publiczne, red. A. Pomorska, Lublin 2006, s. 131. 
wzmocnienie w przypadku przyjęcia stanowiska, iż ustawy budżetowe stanowią nie tyle przejaw zwykłej działalności ustawodawczej parlamentu, co odrębny i niezbywalny atrybut tej władzy, do realizacji którego konieczna jest forma oraz ranga usta$w^{5}$. Założenie, iż autoryzacja parlamentarna oraz nadanie budżetowi rangi i formy ustawy stanowi odrębny atrybut władzy finansowej państwa, przemawia również za przyjęciem bardziej surowych kryteriów oceny regulacji normujących instytucję przeniesień.

Celem artykułu jest analiza zmian w zakresie przepisów dotyczących dokonywania przez Radę Ministrów przeniesień planowanych wydatków budżetowych, które zostały wprowadzone w związku z koniecznością przeciwdziałania skutkom COVID-19. W pierwszej części opracowania omówiona została regulacja upoważniająca do zastosowania tego instrumentu w przypadku ogłoszenia stanu zagrożenia epidemicznego albo stanu epidemii. W drugiej natomiast analizie poddano przepisy dotyczące przenoszenia wydatków budżetowych w przypadku uruchomienia programu mobilizacji gospodarki. Realizacja wskazanego celu badawczego pozwoliła na sformułowanie tezy, iż wprowadzone zmiany w znaczący sposób poszerzają zakres luzu decyzyjnego egzekutywy w sferze wykonywania budżetu państwa, co może rodzić wątpliwości w świetle konstytucyjnej zasady wyłączności władzy ustawodawczej w kształtowaniu dochodów i wydatków państwa.

\section{Przeniesienia planowanych wydatków budżetowych w przypadku ogłoszenia stanu zagrożenia epidemicznego albo stanu epidemii}

W drodze ustawy o szczególnych rozwiązaniach związanych z zapobieganiem, przeciwdziałaniem i zwalczaniem COVID-19, innych chorób zakaźnych oraz wywołanych nimi sytuacji kryzysowych wprowadzono do polskiego systemu prawnego przepis zawierający nowe upoważnienie dla Rady Ministrów do dokonywania przeniesień planowanych wydatków budżetowych ${ }^{6}$. W przypadku ogłoszenia stanu zagrożenia epidemicznego albo stanu epidemii Rada Ministrów może, w drodze rozporządzenia, dokonywać przeniesienia planowanych wydatków budżetowych między częściami

5 Zob. T. Dębowska-Romanowska, Charakter prawny ustawy budżetowej - nowe pytania czy nowe odpowiedzi na stare pytania?, w: Nauka finansów publicznych i prawa finansowego w Polsce. Dorobek i kierunki rozwoju, red. J. Głuchowski, C. Kosikowski, J. Szołno-Koguc, Lublin 2008, s. 225.

6 Art. 26 ustawy z dnia 2 marca 2020 r. o szczególnych rozwiązaniach związanych z zapobieganiem, przeciwdziałaniem i zwalczaniem COVID-19, innych chorób zakaźnych oraz wywołanych nimi sytuacji kryzysowych, Dz. U. z 2020 r. poz. 1842 z późn. zm. (dalej: ustawa o przeciwdziałaniu COVID-19). 
i działami budżetu państwa w celu wsparcia realizacji zadań wynikających z przepisów o zapobieganiu oraz zwalczaniu zakażeń i chorób zakaźnych u ludzi, uwzględniając wysokość oraz rodzaj koniecznego wsparcia i bieżące wykonanie wydatków w poszczególnych częściach i działach budżetu państwa7. Analizując powołaną regulację, należy zauważyć, że zawarta w niej treść upoważnienia w sposób wyraźny nawiązuje do konstrukcji przepisu normującego przenoszenie wydatków w przypadku wprowadzenia stanu nadzwyczajnego.

Po pierwsze, w obydwu sytuacjach upoważnienie do dokonania przeniesień wydatków aktualizuje się na skutek wejścia w życie aktu prawnego wydanego w związku z zaistnieniem zdarzeń faktycznych, z którymi wiążą się zagrożenia wymagające zastosowania środków o szczególnym charakterze, mających na celu zapewnienie ochrony nadrzędnej wartości, jaką jest bezpieczeństwo człowieka. W przypadku analizowanego przepisu konieczne jest ogłoszenie stanu zagrożenia epidemicznego albo stanu epidemii. Terminy „stan zagrożenia epidemicznego”, „stan epidemii” oraz „epidemia” zostały zdefiniowane w treści ustawy o zapobieganiu oraz zwalczaniu zakażeń i chorób zakaźnych u ludzi ${ }^{8}$. I tak, przez „stan zagrożenia epidemicznego" należy rozumieć sytuację prawną wprowadzoną na danym obszarze w związku z ryzykiem wystąpienia epidemii w celu podjęcia określonych w ustawie działań zapobiegawczych. „Stan epidemii” został zdefiniowany jako sytuacja prawna wprowadzona na danym obszarze $\mathrm{w}$ związku $\mathrm{z}$ wystąpieniem epidemii $\mathrm{w}$ celu podjęcia określonych w ustawie działań przeciwepidemicznych i zapobiegawczych dla zminimalizowania skutków epidemii. Z kolei pod pojęciem „epidemii” należy rozumieć wystąpienie na danym obszarze zakażeń lub zachorowań na chorobę zakaźną w liczbie wyraźnie większej niż we wcześniejszym okresie albo wystąpienie zakażeń lub chorób zakaźnych dotychczas niewystępujących ${ }^{9}$. Zarówno stan zagrożenia epidemicznego, jak i stan epidemii są zatem sytuacjami prawnymi, których ogłoszenie i odwołanie następuje w drodze rozporządzenia ${ }^{10}$.

Po drugie, tak w przypadku wprowadzenia stanu nadzwyczajnego, jak i stanów zagrożenia epidemicznego lub epidemii Radzie Ministrów przysługuje prawo do dokonywania przeniesień planowanych wydatków budżetowych między częściami i działami budżetu państwa. W aspekcie przedmiotowym zakres upoważnienia został zatem określony w najszerszym $\mathrm{z}$ możliwych ujęć. Z jednej strony obejmuje

7 Art. 180a ustawy z dnia 27 sierpnia 2009 r. o finansach publicznych, tekst jednolity: Dz. U. z 2021 r. poz. 305 (dalej: ustawa o finansach publicznych).

8 Ustawa z dnia 5 grudnia 2008 r. o zapobieganiu oraz zwalczaniu zakażeń i chorób zakaźnych u ludzi, tekst jednolity: Dz. U. z 2020 r. poz. 1845 (dalej: ustawa o zwalczaniu chorób zakaźnych)

9 Art. 2 pkt 9, pkt 22 i pkt 23 ustawy o zwalczaniu chorób zakaźnych.

10 Art. 46 ust. 1 i 2 ustawy o zwalczaniu chorób zakaźnych. 
bowiem prawo do przenoszenia wydatków pomiędzy wszystkimi częściami budżetu państwa, w tym częściami podmiotów cieszących się tzw. autonomią budżetową. $\mathrm{Z}$ drugiej zaś statuuje upoważnienie do modyfikacji układu działowego budżetu. W tym kontekście należy podkreślić, że układ działowy budżetu przesądza o ekonomicznej treści tego planu ${ }^{11}$. Ponieważ analiza budżetu w przekroju działowym umożliwia ocenę stopnia zaangażowania środków budżetowych w realizację publicznych, społecznych i gospodarczych funkcji państwa, niezależnie od tego w jakiej części budżetu są ponoszone ${ }^{12}$, ochrona klasyfikacji działowej jest uzasadniona zarówno względami ekonomicznymi, jak i parlamentarną kontrolą wydatków ${ }^{13}$.

Po trzecie, w obydwu sytuacjach celem dokonania przeniesień jest zapewnienie realizacji zadań wynikających z przepisów dotyczących danych stanów. Różnica polega na tym, że w przypadku stanu zagrożenia epidemicznego albo stanu epidemii nie posłużono się sformułowaniem „realizacja zadań”, lecz „wsparcie realizacji zadań", a także wskazano wprost, że chodzi o zadania wynikające z przepisów o zapobieganiu oraz zwalczaniu zakażeń i chorób zakaźnych u ludzi. Celem dokonania przeniesień może być zatem dofinansowanie zadań, których koszty co do zasady są ponoszone zgodnie z przepisami ustawy o zapobieganiu oraz zwalczaniu chorób zakaźnych ${ }^{14}$. Warto również zauważyć, że w analizowanym przepisie upoważniającym w sposób bardziej szczegółowy określono wytyczne dotyczące treści rozporządzenia w sprawie przeniesienia planowanych wydatków. Obok wskazówek wyznaczających treść rzeczonego aktu zawarto bowiem także dyrektywę dotyczącą sposobu jego tworzenia, zobowiązując Radę Ministrów do uwzględnienia wysokości oraz rodzaju koniecznego wsparcia i do bieżącego wykonania wydatków w poszczególnych częściach i działach budżetu państwa.

Stan zagrożenia epidemicznego lub stan epidemii na obszarze województwa lub jego części ogłasza wojewoda, na wniosek państwowego wojewódzkiego inspektora sanitarnego. Jeżeli zagrożenie epidemiczne lub epidemia występują na obszarze więcej niż jednego województwa, stany te ogłasza minister właściwy do spraw

11 Zob. E. Chojna-Duch, Polskie prawo finansowe. Finanse publiczne, Warszawa 2007, s. 143.

12 Zob. S. Owsiak, Finanse publiczne. Teoria i praktyka, Warszawa 2005, s. 415; K. Gąsiorek, Klasyfikacja budżetowa 2018, Warszawa 2018, s. 17.

13 Zob. E. Kosiński, Procedura budżetowa a deficyt. Zagadnienia prawne na tle porównawczym, Warszawa 2001, s. 147; M. Duda, w: Ustawa o finansach publicznych. Komentarz, red. P. Smoleń, Warszawa 2014, s. 883.

14 Koszty finansowania zadań polegających na zapobieganiu oraz zwalczaniu chorób zakaźnych u ludzi w przeważającej mierze są finansowane z części budżetu państwa, której dysponentem jest minister właściwy do spraw zdrowia, bądź na zasadach określonych w ustawie z dnia 27 sierpnia 2004 r. o świadczeniach opieki zdrowotnej finansowanych ze środków publicznych, tekst jednolity: Dz. U. z 2020 r. poz. 1398. 
zdrowia $\mathrm{w}$ porozumieniu $\mathrm{z}$ ministrem właściwym do spraw administracji publicznej, na wniosek Głównego Inspektora Sanitarnego ${ }^{15}$. Ocena sytuacji faktycznej przesądzającej o konieczności promulgacji rzeczonych stanów należy do organów Państwowej Inspekcji Sanitarnej i jest dokonywana na podstawie konkretnych danych ustalonych $\mathrm{w}$ drodze postępowania wyjaśniającego ${ }^{16}$. Oznacza to, że decyzja, od podjęcia której zależy aktualizacja upoważnienia do dokonania przeniesień wydatków budżetowych, cechuje się niewielkim stopniem uznaniowości. Jednocześnie należy zauważyć, że dodany do ustawy o finansach publicznych przepis nie zawiera zastrzeżenia, że stan zagrożenia epidemicznego lub stan epidemii musi dotyczyć obszaru całego kraju. Uzasadnione wydaje się zatem twierdzenie, że Radzie Ministrów przysługuje upoważnienie do dokonywania przeniesień planowanych wydatków między częściami i działami budżetu państwa również wówczas, gdy stany te zostały ogłoszone wyłącznie w odniesieniu do jednego województwa lub jego części. Przyjęcie takiego rozwiązania w sposób oczywisty rodzi pytanie o to, czy w przypadku zaistnienia powyższych okoliczności organom władzy wykonawczej winno przysługiwać prawo do tak szeroko zakrojonej ingerencji w określoną ustawą budżetową strukturę wydatków państwa.

Jak już zaznaczono, przepis upoważniający stanowi, że przeniesienia planowanych wydatków budżetowych mogą być dokonywane „w celu wsparcia realizacji zadań wynikających z przepisów o zapobieganiu oraz zwalczaniu zakażeń i chorób zakaźnych". Ponieważ unormowania statuujące tego rodzaju kompetencje nie mogą podlegać wykładni rozszerzającej, prima facie nasuwa się wniosek, że określony $\mathrm{w}$ powyższy sposób cel ingerencji $\mathrm{w}$ treść budżetu nie pozostawia pola do nadużyć polegających na stosowaniu instrumentu przeniesień zgodnie $\mathrm{z}$ aktualnymi potrzebami politycznymi czy oczekiwaniami społecznymi. Analiza aktu wykonawczego wydanego na podstawie rzeczonego przepisu prowadzi jednak do odmiennych konkluzji. $\mathrm{W}$ drodze rozporządzenia $\mathrm{w}$ sprawie przeniesienia planowanych wydatków budżetowych, określonych w ustawie budżetowej na rok 2020, dokonano przeniesień wydatków między częściami budżetu państwa, których dysponentem jest minister gospodarki i żeglugi śródlądowej oraz między działami w części 21 - Gospodarka morska ${ }^{17}$. Z treści uzasadnienia to tego aktu wynika, że celem dokonanych zmian było: 1) wsparcie finansowe właścicieli lub armatorów jachtów

15 Art. 46 ust. 1 i 2 ustawy o zwalczaniu chorób zakaźnych.

16 Szerzej zob. A. Krakała, Stan zagrożenia epidemicznego oraz stan epidemii na tle stanu klęski żywiołowej, w: Problemy bezpieczeństwa państwa. Wybrane aspekty, red. M. Chrabkowski, C. Tatarczuk, J. Tomaszewski, W. Wosek, Gdynia 2018, s. 89-93.

17 Rozporządzenie Rady Ministrów z dnia 19 czerwca 2020 r. w sprawie przeniesienia planowanych wydatków budżetowych, określonych w ustawie budżetowej na rok 2020, Dz. U. z 2020 r. poz. 1067. 
komercyjnych prowadzących działalność polegającą na odpłatnym udostępnieniu statku w celach połowów rekreacyjnych; 2) zwiększenie subwencji na utrzymanie i rozwój potencjału dydaktycznego i badawczego dla Uniwersytetu Morskiego w Gdyni oraz Akademii Morskiej w Szczecinie; 3) modernizacja zestawu pchanego „Westerplatte II” w Technikum Żeglugi Śródlądowej we Wrocławiu ${ }^{18}$. Uzasadniając konieczność dokonania rzeczonych przeniesień wskazano, że uruchomienie tej procedury pozwoli na udzielenie pomocy z budżetu państwa podmiotom, które poniosły straty w związku z epidemią COVID $-19^{19}$. Potrzeba udzielenia wsparcia wskazanym podmiotom nie budzi wątpliwości. Trudno natomiast uznać, że wydając rzeczone rozporządzenie dokonano przeniesienia planowanych wydatków „W celu wsparcia realizacji zadań wynikających z przepisów o zapobieganiu oraz zwalczaniu zakażeń i chorób zakaźnych". Zadania określone w tych przepisach nie obejmują bowiem udzielania pomocy finansowej przedsiębiorcom i innym podmiotom dotkniętym ekonomicznymi skutkami epidemii ${ }^{20}$.

$\mathrm{Na}$ tle powyższych uwag nasuwa się pytanie natury bardziej ogólnej, czy okoliczność, jaką jest ogłoszenie stanu zagrożenia epidemicznego albo stanu epidemii, uzasadnia nadanie Radzie Ministrów takich samych kompetencji w zakresie przenoszenia planowanych wydatków budżetowych jak wprowadzenie stanu nadzwyczajnego. W doktrynie prawa konstytucyjnego wskazuje się, że w państwie demokratycznym termin „stan nadzwyczajny” oznacza reżim prawny wprowadzony w razie wystąpienia szczególnego zagrożenia, którego usunięcie jest możliwe tylko przy pomocy środków o wyjątkowym charakterze ${ }^{21}$. Jedną z cech definicyjnych tego stanu jest zatem to, że implikuje zastosowanie nadzwyczajnych środków, w tym polegających na określeniu na nowo relacji między organami władzy publicznejej ${ }^{22}$. Zaistnienie nadzwyczajnych okoliczności niewątpliwie rodzi potrzebę realizacji dodatkowych zadań budżetowych, co może wiązać się z koniecznością modyfikacji zakresu upoważnień do dokonywania wydatków określonych w przepisach ustawy

18 Zob. uzasadnienie do projektu rozporządzenia w sprawie przeniesienia planowanych wydatków budżetowych, określonych w ustawie budżetowej na rok 2020, https://legislacja.rcl.gov.pl/ projekt/12335051/katalog/12695098\#12695098 [dostęp: 16.07.2020 r.].

19 Tamże.

20 Art. 46 ust. 4 ustawy o zwalczaniu chorób zakaźnych statuuje podstawy prawne do ustanowienia $\mathrm{w}$ drodze rozporządzenia ograniczeń, których rezultatem może być pogorszenie sytuacji ekonomicznej podmiotów organizujących morskie połowy rekreacyjne. Podstawy prawne do udzielania tym podmiotom wsparcia finansowego ze środków budżetu państwa zawarte są jednak w przepisach odrębnych (art. 15ma ustawy o przeciwdziałaniu COVID-19).

21 K. Prokop, Stany nadzwyczajne w Konstytucji Rzeczypospolitej Polskiej, Białystok 2005, s. 9.

22 Zob. M. Brzeziński, Stany nadzwyczajne w polskich konstytucjach, Warszawa 2007, s. 22; E. Kurzępa, Stany nadzwyczajne w polskim porzadku prawnym, Warszawa 2017, s. 62. 
budżetowej. Ponieważ działania mające na celu przeciwdziałanie zagrożeniom muszą być podejmowane szybko, a ich charakter może ulegać dynamicznym zmianom, uzasadnione jest wprowadzanie takich regulacji prawnych, które przesuwają punkt ciężkości podejmowania decyzji z zakresu finansów publicznych na rzecz organów władzy wykonawczej ${ }^{23}$. Norma ustawy o finansach publicznych statuująca upoważnienie dla Rady Ministrów do przeniesienia planowanych wydatków budżetowych między częściami i działami budżetu państwa, w celu realizacji zadań wynikających z przepisów dotyczących wprowadzenia stanu nadzwyczajnego, znajduje zatem uzasadnienie konstytucyjne, wpisując się w stanowiący istotę stanów nadzwyczajnych ekstraordynaryjny tryb funkcjonowania państwa.

Stany zagrożenia epidemicznego i epidemii, podobnie jak stany nadzwyczajne, wiążą się z rzeczywistym i bezpośrednim zagrożeniem. Zarówno stan epidemii, jak i stan zagrożenia epidemicznego mają na celu zapewnienie ochrony wartości nadrzędnych, tj. życia, zdrowia i bezpieczeństwa sanitarnego obywateli, co wiąże się z wprowadzeniem pewnych ograniczeń wolności i praw ${ }^{24}$. Niemniej jednak jest rzeczą oczywistą, że ogłoszenie rzeczonych stanów nie jest tożsame z proklamacją stanu nadzwyczajnego wprowadzanego w sytuacjach zagrożeń o charakterze szczególnym, dla usunięcia których nie wystarczają zwykłe środki konstytucyjne ${ }^{25}$. W literaturze przedmiotu zwraca się uwagę, że stan zagrożenia epidemicznego oraz stan epidemii są „miękkimi” reżimami prawnymi, a ich ogłoszenie winno poprzedzać, jeżeli sytuacja się nie poprawi, wprowadzenie stanu nadzwyczajnego ${ }^{26}$. Sytuacje podlegające kwalifikacji jako stan zagrożenia epidemicznego lub stan epidemii stanowią bowiem zagrożenie, lecz nie „zagrożenie szczególne” w rozumieniu przepisów Konstytucji RP i nie godzą w normalne funkcjonowanie instytucji państwowych $^{27}$. Nie oznacza to oczywiście, że działanie tych instytucji nie może być

23 Zob. M. Zubik, Budżet państwa w polskim prawie konstytucyjnym, Warszawa 2001, s. 304.

24 Zob. postanowienie SN z dnia 6 kwietnia 2020 r., I NSW 12/20, LEX nr 2944338.

25 Art. 228 ust. 1 Konstytucji Rzeczypospolitej Polskiej z dnia 2 kwietnia 1997 r., Dz. U. z 1997 r. Nr 78, poz. 483, sprost. Dz. U. z 2001 r. Nr 28, poz. 319 z późn. zm. (dalej: Konstytucja RP).

26 Zob. B. Szmulik, J. Szymanek, O możliwości wprowadzenia stanu nadzwyczajnego w kontekście epidemii koronawirusa, Przegląd Legislacyjny 2020, t. 27, nr 1, s. 16-17. W piśmiennictwie zwraca się uwagę, że w sytuacji epidemii koronawirusa w grę wchodzą dwie możliwości, tj. wprowadzenie stanu wyjątkowego albo wprowadzenie stanu klęski żywiołowej. Tamże, s. 18-19.

27 Konstytucja RP nie zawiera definicji legalnej „szczególnego zagrożenia”. W doktrynie prawa konstytucyjnego ugruntowane jest jednak stanowisko, iż sytuacje podlejące takiej kwalifikacji godzą nie tylko w podstawowe interesy społeczeństwa, ale także zakłócają normalne funkcjonowanie instytucji państwowych. Szerzej zob. E. Kurzępa, Stany nadzwyczajne..., s. 76; S. Steinborn, w: Konstytucja RP, t. 2. Komentarz do art. 87-243, red. M. Safjan, L. Bosek, 2016 [baza danych Legalis], Komentarz do art. 228 , teza 2 oraz powoływana tam literatura. 
w jakimś stopniu utrudnione ${ }^{28}$. Jeżeli jednak proces legislacyjny nie jest zakłócony, ergo istnieje możliwość nowelizacji ustawy budżetowej, trudno wskazać legitymację konstytucyjną do tak istotnego przesunięcia kompetencji w zakresie determinowania strony wydatkowej budżetu państwa na rzecz organów egzekutywy.

Jak już zaznaczono, wystąpienie zagrożenia epidemicznego lub epidemii niewątpliwie może wywoływać znaczne ograniczenia w działaniu właściwych organów administracji publicznej ze względu na nieadekwatność posiadanych sił i środków, a zatem może stanowić sytuację kryzysową w rozumieniu ustawy o zarządzaniu kryzysowym ${ }^{29}$. Sytuacja kryzysowa jest jednak czymś rodzajowo odmiennym od konstytucyjnych stanów nadzwyczajnych i w ocenie Trybunału Konstytucyjnego winna zostać zaliczona do „normalnego” funkcjonowania państwa ${ }^{30}$. Wydaje się zatem, że w przypadku wystąpienia epidemii, która wprawdzie utrudnia, lecz nie wyklucza możliwości prowadzenia prac legislacyjnych, wzmocnienie uprawnień egzekutywy w sferze determinowania wydatków państwa nie znajduje uzasadnienia. Brak jest bowiem podstaw konstytucyjnych do modyfikacji „normalnego” porządku zadaniowo-kompetencyjnego w systemie organów władzy publicznej ${ }^{31}$. Z kolei w przypadku epidemii stanowiącej zagrożenie szczególne w rozumieniu przepisów Konstytucji RP istnieje przesłanka do wprowadzenia stanu nadzwyczajnego, a tym samym dokonania przeniesień planowanych wydatków budżetowych.

\section{Przeniesienia planowanych wydatków budżetowych w przypadku uruchomienia programu mobilizacji gospodarki}

Kolejny przepis upoważniający Radę Ministrów do dokonywania przeniesień wydatków budżetowych wprowadzono do polskiego systemu prawnego $\mathrm{w}$ drodze ustawy o zmianie ustawy o szczególnych rozwiązaniach związanych z zapobieganiem, przeciwdziałaniem i zwalczaniem COVID-19, innych chorób zakaźnych oraz

28 Przykładem takich ograniczeń może być konieczność procedowania ustaw z wykorzystaniem narzędzi zdalnej komunikacji.

29 Art. 3 pkt 1 ustawy z dnia 26 kwietnia 2007 r. o zarządzaniu kryzysowym, tekst jednolity: Dz. U. z 2020 r. poz. 1856 z późn. zm.

30 Zob. wyrok TK z dnia 21 kwietnia 2009 r., K 50/07, OTK ZU 2009, z. 4A, poz. 51.

31 Podstawą takich modyfikacji mogą być regulacje prawne dotyczące stanów nadzwyczajnych. Szerzej zob. M. Miemiec, Stany nadzwyczajne (stan wojenny, stan wyjątkowy, stan klęski żywiołowej) w Konstytucji Rzeczypospolitej Polskiej, Przegląd Prawa i Administracji 2016, t. 106, s. 19-28. 
wywołanych nimi sytuacji kryzysowych oraz niektórych innych ustaw ${ }^{32}$. W myśl dodanej regulacji, w przypadku uruchomienia programu mobilizacji gospodarki Rada Ministrów może, w drodze rozporządzenia, dokonywać przeniesienia planowanych wydatków budżetowych między częściami i działami budżetu państwa w celu wsparcia realizacji zadań wynikających z przepisów o organizowaniu zadań na rzecz obronności państwa realizowanych przez przedsiębiorców, uwzględniając wysokość oraz rodzaj koniecznego wsparcia i bieżące wykonanie wydatków w poszczególnych częściach i działach budżetu państwa ${ }^{33}$.

Przyznanie Radzie Ministrów upoważnienia do dokonywania przeniesień w przypadku uruchomienia programu mobilizacji gospodarki wiąże się ze zmianami, jakie w związku z COVID-19 wprowadzono do ustawy o organizowaniu zadań na rzecz obronności państwa realizowanych przez przedsiębiorców ${ }^{34}$. Istotą powyższych modyfikacji było rozszerzenie zakresu znaczeniowego pojęcia „zadań na rzecz obronności państwa” o zadania podejmowane w sytuacji zagrożenia zdrowia lub życia ludzkiego ${ }^{35}$. W konsekwencji treścią programu mobilizacji gospodarki objęto dwie nowe kategorie przedsięwzięć. Pierwszą stanowią zadania organów administracji rządowej w zakresie prowadzenia działań o charakterze organizacyjno-planistycznym, związanych z przygotowaniem gospodarki do funkcjonowania w warunkach zagrożenia zdrowia i życia ludzkiego. Do drugiej zaliczają się zadania, jakie mogą być nałożone na przedsiębiorców o szczególnym znaczeniu gospodarczo-obronnym w zakresie wytwarzania i dystrybucji produktów leczniczych, środków spożywczych specjalnego przeznaczenia żywieniowego, środków ochronnych i wyrobów medycznych oraz udzielania świadczeń zdrowotnych na potrzeby ludności Polski w sytuacjach zagrożenia życia i zdrowia ludzkiego ${ }^{36}$.

Ustawa o finansach publicznych stanowi, iż zdarzeniem aktualizującym upoważnienie do dokonania przez Radę Ministrów przeniesień planowanych wydatków budżetowych jest uruchomienie programu mobilizacji gospodarki. Program

32 Art. 38 pkt 2 ustawy z dnia 31 marca 2020 r. o zmianie ustawy o szczególnych rozwiązaniach związanych z zapobieganiem, przeciwdziałaniem i zwalczaniem COVID-19, innych chorób zakaźnych oraz wywoływanych nimi sytuacji kryzysowych oraz niektórych innych ustaw, Dz. U. z 2020 r. poz. 568 z późn. zm.

33 Art. 180b ustawy o finansach publicznych.

34 Ustawa $z$ dnia 23 sierpnia 2001 r. o organizowaniu zadań na rzecz obronności państwa realizowanych przez przedsiębiorców, Dz. U. z 2020 r. poz. 1669 z późn. zm. (dalej: ustawa o organizowaniu zadań na rzecz obronności państwa).

35 Art. 19 pkt 1 lit. a i lit. b ustawy o przeciwdziałaniu COVID-19. Do dnia wejścia w życie ustawy o przeciwdziałaniu COVID-19 do kategorii tej zaliczały się wyłącznie zadania realizowane w warunkach zagrożenia bezpieczeństwa państwa i w czasie wojny.

Art. 4a ust. 2 pkt 1 i 2 a ustawy o organizowaniu zadań na rzecz obronności państwa. 
mobilizacji gospodarki jest ustalany przez Radę Ministrów. Ponieważ stosuje się do niego przepisy o ochronie informacji niejawnych, szczegóły tej instytucji nie są znane $^{37}$. W literaturze przedmiotu wskazuje się, że jest to dokument planistyczny, określający zadania związane z przygotowaniem gospodarki narodowej do wzmożonych świadczeń na rzecz obronności w okresie zagrożenia bezpieczeństwa państwa i w czasie wojny ${ }^{38}$. Nadrzędnym celem programu jest stworzenie warunków dla przedsiębiorców o szczególnym znaczeniu gospodarczo-obronnym do świadczenia usług produkcyjno-remontowych w zakresie uzbrojenia i sprzętu wojskowego na rzecz Sił Zbrojnych RP oraz organów porządku publicznego. Instytucja ta służy również określeniu możliwości produkcyjno-usługowych wybranych działów gospodarki oraz możliwości zaspokojenia potrzeb bytowych ludności ${ }^{39}$. Nałożenie na przedsiębiorcę zadania ujmowanego w programie mobilizacji gospodarki jest tożsame z zobowiązaniem takiego podmiotu do utrzymywania mocy produkcyjnych lub/i remontowych niezbędnych do realizacji tego zadania ${ }^{40}$. W związku z powyższym przedsiębiorcom są udzielane dotacje celowe z budżetu państwa. Warto dodać, że w obowiązującym stanie prawnym dotacje te są udzielane z części, których dysponentami są minister obrony narodowej oraz minister właściwy do spraw gospodarki ${ }^{41}$.

Program mobilizacji gospodarki jest sporządzany w ramach programowania obronnego, co cztery lata, na piętnastoletni okres planistyczny rozpoczynający się w roku nieparzystym ${ }^{42}$. Z kolei programowanie obronne odbywa się na podstawie ustaleń przyjętych w strategii bezpieczeństwa narodowego oraz w wytycznych Rady Ministrów do programowania przygotowań obronnych, których projekt sporządza raz na cztery lata minister obrony narodowej ${ }^{43}$. Ustanawianie programu mobilizacji

37 Art. 4a ust. 1 i ust. 3 ustawy o organizowaniu zadań na rzecz obronności państwa.

38 M.M. Nawrot, Rola programu mobilizacji gospodarki oraz systemu rezerw państwowych w przygotowaniach obronnych państwa, Zeszyt Problemowy TWO 2011, nr 1, s. 128.

39 Szerzej zob. M.M. Nawrot, Rola programu..., s. 129-130; T. Nalepa, Modelowe rozwiązania w zakresie finansowania zadań utrzymywania mocy produkcyjnych i remontowych, niezbędnych do realizacji prac wynikajacych z PMG, Wiedza Obronna 2011, nr 2, s. 16-17.

40 Zob. T. Nalepa, Nakładanie zadań wynikających z programu mobilizacji gospodarki na przedsiębiorców o szczególnym znaczeniu gospodarczo-obronnym, Wiedza Obronna 2013, nr 4, s. 99.

$41 \$ 2$ rozporządzenia Rady Ministrów z dnia 20 lipca 1993 r. w sprawie określania organów właściwych do nakładania niektórych obowiązków i zadań niezbędnych na potrzeby ochrony państwa oraz zasad odpłatności za wykonywanie tych zadań i przeprowadzania kontroli ich realizacji, Dz. U. z 1993 r. Nr 69, poz. 331 z późn. zm.

$42 \$ 9$ rozporządzenia Rady Ministrów z dnia 15 czerwca 2004 r. w sprawie warunków i trybu planowania i finansowania zadań wykonywanych w ramach przygotowań obronnych państwa przez organy administracji rządowej i organy samorządu terytorialnego, Dz. U. z 2020 r. , poz. (dalej: rozporządzenie w sprawie planowania i finansowania przygotowań obronnych).

$43 \$ 8$ rozporządzenia w sprawie planowania i finansowania przygotowań obronnych. 
gospodarki stanowi zatem stały element systemu bezpieczeństwa państwa. Od ustanawiania programu należy odróżnić jego uruchomienie, które może nastąpić wyłącznie w dwóch sytuacjach. Pierwszą jest pojawienie się bezpośredniego zewnętrznego zagrożenia państwa, drugą - ochrona ludności przed zagrożeniami występującymi na terytorium Rzeczypospolitej Polskiej, których charakter i rozmiar wymaga użycia środków niebędących w posiadaniu właściwych organów administracji rządowej lub posiadanych $\mathrm{w}$ niewystarczającej ilości ${ }^{4}$. Uruchomienie programu następuje w drodze rozporządzenia Prezesa Rady Ministrów, przy czym może to nastąpić selektywnie albo w pełnym zakresie ${ }^{45}$.

Analizując przepis statuujący upoważnienie do dokonywania przeniesień planowanych wydatków budżetu państwa w przypadku uruchomienia programu mobilizacji gospodarki, należy zwrócić uwagę na kilka kwestii. Po pierwsze, zakres przedmiotowy rzeczonego upoważnienia obejmuje przenoszenie środków między częściami i działami budżetu państwa. Podobnie jak w przypadku ogłoszenia stanu zagrożenia epidemicznego albo stanu epidemii Rada Ministrów może dokonywać zmian naruszających działowy układ budżetu.

Po drugie, wydatki mogą być przenoszone „w celu wsparcia realizacji zadań wynikających z przepisów o organizowaniu zadań na rzecz obronności państwa realizowanych przez przedsiębiorców". Oznacza to, że w wyniku dokonanych przeniesień dofinansowaniu mogą podlegać nie tylko zadania ujęte w programie mobilizacji gospodarki, lecz także przedsięwzięcia w zakresie: militaryzacji, planowania operacyjnego, szkolenia obronnego, czy też zadania wynikające z obowiązków państwa-gospodarza, obejmujące przedsięwzięcia związane z udzieleniem wsparcia przybywającym na terytorium Polski wojskom sojuszniczym ${ }^{46}$.

Po trzecie, warunkiem aktualizacji upoważnienia do dokonywania przeniesień wydatków jest wydanie przez Radę Ministrów rozporządzenia w sprawie uruchomienia programu mobilizacji gospodarki. Ustawa o finansach publicznych nie zawiera zastrzeżenia, iż przeniesienia mogą być dokonywane wyłącznie w sytuacji uruchomienia programu w pełnym zakresie. W związku z powyższym wydaje się, że przesłanka ta może zostać uznana za spełnioną również w przypadku uruchomienia selektywnego. Jak już zaznaczono, uruchomienie programu mobilizacji gospodarki może nastąpić wyłącznie w dwóch sytuacjach, z których pierwszą jest pojawienie się „bezpośredniego zewnętrznego zagrożenia państwa”. Uwagę zwraca fakt, iż zastosowana formuła jest identyczna $\mathrm{z}$ uzasadniającą zarządzenie

44 Art. 4 b ust. 6 ustawy o organizowaniu zadań na rzecz obronności państwa.

45 Art. 4 b ust. 1 i 2 ustawy o organizowaniu zadań na rzecz obronności państwa.

46 Art. 2 w zw. z art. 4 a ustawy o organizowaniu zadań na rzecz obronności państwa. 
mobilizacjii ${ }^{47}$. Adaptując ustalenia doktryny prawa konstytucyjnego, należy zatem przyjąć, że źródło zagrożenia musi znajdować się poza granicami $\mathrm{RP}^{48}$, natomiast samo zagrożenie dotyczyć atrybutów państwa polskiego ${ }^{49}$. Z kolei bezpośredniość zagrożenia oznacza, że jest ono aktualne, tj. występuje w momencie wydawania rozporządzenia oraz ma charakter realny, a nie tylko potencjalny ${ }^{50}$. Brzmienie przepisów określających treść programu mobilizacji gospodarki zdaje się nadto wskazywać, iż zagrożenie stanowiące przesłankę uruchomienia tego programu winno mieć charakter militarny. W tym kontekście należy zauważyć, że zagrożenie bezpieczeństwa państwa stanowi również jedną z przesłanek wprowadzenia stanu wojennego ${ }^{51}$. Różnica polega na tym, że nie musi mieć ono charakteru bezpośredniego. W związku z powyższym rodzi się pytanie, czy jest możliwe uruchomienie programu mobilizacji gospodarki bez uprzedniego lub jednoczesnego wprowadzenia stanu wojennego. Odmienny sposób określenia przesłanek skłania do przyjęcia stanowiska, iż mobilizacja gospodarki może wyprzedzać stan wojenny, np. służąc przygotowaniu do tego stanu. Niemniej należy zwrócić uwagę na to, że cecha bezpośredniości przesądza o niedopuszczalności uruchomienia programu mobilizacji gospodarki w celu przygotowania do zagrożenia, jeżeli zagrożenie to jest wprawdzie realne, ale w odniesieniu do państwa polskiego dopiero może się pojawić.

Jak już zaznaczono, drugą przesłanką uruchomienia programu mobilizacji gospodarki jest ochrona ludności przed zagrożeniami występującymi na terytorium $\mathrm{RP}$, których charakter i rozmiar wymaga użycia środków niebędących w posiadaniu właściwych organów administracji rządowej lub posiadanych w niewystarczającej ilości. Ustawa wskazuje wyraźnie, że zagrożenie musi dotyczyć ludności i występować na terytorium kraju, niezależnie od tego, gdzie zlokalizowane jest jego źródło. Z kolei źródłem zagrożenia może być zarówno działalność człowieka, jak i siły natury, w tym rozprzestrzenianie się chorób zakaźnych. Warunkiem jest, aby charakter i rozmiar zagrożenia wymagał użycia środków niebędących w posiadaniu właściwych organów administracji rządowej lub posiadanych w niewystarczającej ilości.

Na tle powyższych uwag rodzi się wątpliwość, czy zasadne jest przyznanie Radzie Ministrów upoważnienia do dokonywania przeniesień planowanych wydatków budżetowych w przypadku uruchomienia programu mobilizacji gospodarki w takim samym zakresie, co w przypadku ogłoszenia stanu nadzwyczajnego.

47 Art. 136 Konstytucji RP.

48 Zob. B. Szczurowski, w: Konstytucja RP, t. 2. Komentarz..., Komentarz do art. 136, pkt IV, teza 1.

49 Szerzej zob. K. Prokop, Stany nadzwyczajne..., s. 47.

50 Zob. B. Banaszak, Konstytucja Rzeczypospolitej..., s. 759.

51 Art. 229 Konstytucji RP. 
Pojawienie się bezpośredniego zewnętrznego zagrożenia państwa niewątpliwie jest sytuacją nadzwyczajną, która w świetle przepisów ustawy zasadniczej przesądza o dopuszczalności zastosowania środka niemieszczącego się w kategorii zwykłych środków konstytucyjnych ${ }^{52}$. Wydaje się zatem, że legitymacji do wzmocnienia roli egzekutywy w determinowaniu treści budżetu można poszukiwać w wartości, jaką jest konieczność zapewnienia państwu należytego potencjału obronnego. Należy również zauważyć, że sposób określenia pierwszej z przesłanek uruchomienia programu mobilizacji, a w szczególności znamię „bezpośredniości zagrożenia”, znacząco osłabia możliwość nadużywania uprawnień organów władzy wykonawczej w zakresie przenoszenia planowanych wydatków budżetowych.

Zdecydowanie więcej kontrowersji rodzi przyznanie Radzie Ministrów prawa do przenoszenia planowanych wydatków budżetu państwa w sytuacji, gdy program mobilizacji gospodarki został uruchomiony z uwagi na zaistnienie drugiej ze wskazanych wyżej przesłanek. Konieczność ochrony ludności przed zagrożeniami występującymi na terytorium RP, których charakter i rozmiar wymaga użycia środków niebędących w posiadaniu właściwych organów administracji rządowej lub posiadanych w niewystarczającej ilości, odpowiada niektórym cechom sytuacji kryzysowej. Trzeba jednak pamiętać, że o ile w przypadku sytuacji kryzysowej nieadekwatność posiadanych sił i środków musi powodować znaczne ograniczenia w działaniu właściwych organów administracji publicznej, o tyle dla uruchomienia programu mobilizacji gospodarki wystarcza stwierdzenie samego braku odpowiednich środków. Okolicznością uzasadniającą uruchomienie programu może być zatem nawet taka sytuacja faktyczna, której nie można przypisać znamion sytuacji kryzysowej. Przyznanie Radzie Ministrów upoważnienia do dokonywania zasadniczych zmian w budżecie w okolicznościach, które bez wątpienia nie wiążą się z ekstraordynaryjną formą funkcjonowania państwa, może budzić poważne wątpliwości w kontekście zasady wyłączności władzy ustawodawczej w kształtowaniu dochodów i wydatków państwa. Wypada również zaznaczyć, że sposób określenia przesłanki uruchomienia programu mobilizacji gospodarki, jak również możliwość dokonywania przeniesień w przypadku uruchomienia selektywnego stwarzają pole do nadużywania uprawnień w zakresie stosowania instrumentu przenoszenia wydatków.

52 W doktrynie prawa konstytucyjnego wyrażane jest stanowisko, iż mobilizacji nie można uznać za zwykły środek konstytucyjny. Szerzej zob. E. Kurzępa, Stany nadzwyczajne..., s. 77; K. Prokop, Stany nadzwyczajne..., s. 20. 


\section{Zakończenie}

Spadek poziomu dochodów publicznych oraz konieczność ponoszenia związanych z epidemią wydatków stanowią poważne wyzwanie z perspektywy gospodarowania środkami publicznymi. W związku z powyższym do polskiego systemu prawnego wprowadzono szereg przepisów mających na celu uelastycznienie wykonywania budżetu państwa, w tym unormowania statuujące upoważnienia dla Rady Ministrów do przenoszenia planowanych wydatków budżetowych. Analiza tych regulacji prowadzi do następujących wniosków.

Po pierwsze, konstrukcja przepisów upoważniających do przenoszenia przez Radę Ministrów planowanych wydatków budżetowych w przypadku ogłoszenia stanu zagrożenia epidemicznego albo stanu epidemii oraz w przypadku uruchomienia programu mobilizacji gospodarki w sposób wyraźny nawiązuje do konstrukcji przepisu normującego przenoszenie wydatków w sytuacji wprowadzenia stanu nadzwyczajnego. Przesłanką aktualizacji rzeczonych upoważnień jest bowiem proklamacja określonych w odrębnych ustawach stanów prawnych, zaś formą prawną przeniesienia wydatków - rozporządzenie Rady Ministrów. W identyczny sposób określono także zakres przedmiotowy upoważnienia, który obejmuje zarówno prawo do przenoszenia wydatków pomiędzy wszystkimi częściami budżetu państwa, jak i prawo do modyfikacji układu działowego tego planu. Podobieństwa między nowo wprowadzonymi regulacjami a przepisem upoważniającym do dokonywania przeniesień w przypadku ogłoszenia stanu nadzwyczajnego można również upatrywać w tym, że instrument ten może być stosowany w celu realizacji zadań określonych w ustawach normujących dane stany prawne.

Po drugie, choć stany zagrożenia epidemicznego i epidemii wiążą się z rzeczywistym zagrożeniem, nie jest to zagrożenie o charakterze szczególnym w rozumieniu przepisów Konstytucji RP. Stany faktyczne podlegające powyższej kwalifikacji nie godzą zatem w normalne funkcjonowanie instytucji państwowych, co oznacza, że trudno wskazać legitymację konstytucyjną do tak istotnego przesunięcia kompetencji w zakresie determinowania strony wydatkowej budżetu państwa na rzecz organów władzy wykonawczej.

Po trzecie, przyznanie Radzie Ministrów upoważnienia do dokonywania przeniesień w przypadku uruchomienia programu mobilizacji gospodarki wiąże się ze zmianami, jakie w związku z COVID-19 wprowadzono do ustawy o organizowaniu zadań na rzecz obronności państwa. Ocena rzeczonego przepisu winna uwzględniać charakter zdarzenia przesądzającego o prawie do zastosowania instrumentu przeniesień. I tak, w sytuacji gdy przesłanką uruchomienia programu mobilizacji gospodarki jest pojawienie się bezpośredniego zewnętrznego zagrożenia państwa, 
uzasadnienia dla wzmocnienia roli egzekutywy w determinowaniu treści budżetu można poszukiwać $\mathrm{w}$ wartości, jaką jest konieczność zapewnienia państwu należytego potencjału obronnego. W kontekście zasady wyłączności władzy ustawodawczej w kształtowaniu dochodów i wydatków państwa wątpliwości budzi natomiast przyznanie Radzie Ministrów upoważnienia do dokonywania zasadniczych zmian w budżecie w sytuacji, gdy program ten został uruchomiony z uwagi na konieczność ochrony ludności przed zagrożeniami występującymi na terytorium RP, których charakter i rozmiar wymaga użycia środków niebędących w posiadaniu właściwych organów administracji rządowej lub posiadanych w niewystarczającej ilości.

Po czwarte, pomimo tego, że cele ingerencji w treść budżetu zostały określone precyzyjnie, pojawia się obawa, iż dodane przepisy mogą stanowić pole do nadużyć polegających na stosowaniu instrumentu przeniesień zgodnie z aktualnymi potrzebami politycznymi. Należy bowiem podkreślić, że w świetle poddanych analizie regulacji prawo do dokonania zmian $\mathrm{w}$ budżecie przysługuje również $\mathrm{w}$ sytuacji, gdy stan zagrożenia epidemicznego lub stan epidemii został ogłoszony jedynie na obszarze jednego województwa lub jego części oraz w przypadku selektywnego ogłoszenia planu mobilizacji gospodarki. Powyższe obawy zdają się znajdować potwierdzenie w treści wydanego już rozporządzenia w sprawie przeniesienia planowanych wydatków budżetowych, w drodze którego dokonano zmian w budżecie w celach wykraczających poza cele określone w treści przepisów upoważniających.

\section{Bibliografia}

Banaszak B., Konstytucja Rzeczypospolitej Polskiej. Komentarz, Warszawa 2012.

Borodo A., Konstrukcja prawna ustawy budżetowej, Toruń 2017.

Brzeziński M., Stany nadzwyczajne w polskich konstytucjach, Warszawa 2007.

Chojna-Duch E., Polskie prawo finansowe. Finanse publiczne, Warszawa 2007.

Dębowska-Romanowska T., Charakter i klasyfikacja tzw. wydatków sztywnych a granice swobody politycznej władz państwa, w: Uwarunkowania i bariery w procesie naprawy finansów publicznych, red. J. Głuchowski, A. Pomorska, J. Szołno-Koguc, Lublin 2007.

Dębowska-Romanowska T., Charakter prawny ustawy budżetowej - nowe pytania czy nowe odpowiedzi na stare pytania?, w: Nauka finansów publicznych i prawa finansowego w Polsce. Dorobek i kierunki rozwoju, red. J. Głuchowski, C. Kosikowski, J. Szołno-Koguc, Lublin 2008

Duda M., w: Ustawa o finansach publicznych. Komentarz, red. P. Smoleń, Warszawa 2014.

Gąsiorek K., Klasyfikacja budżetowa 2018, Warszawa 2018.

Kosiński E., Procedura budżetowa a deficyt. Zagadnienia prawne na tle porównawczym, Warszawa 2001. 
Krakała A., Stan zagrożenia epidemicznego oraz stan epidemii na tle stanu klęski żywiołowej, w: Problemy bezpieczeństwa państwa. Wybrane aspekty, red. M. Chrabkowski, C. Tatarczuk, J. Tomaszewski, W. Wosek, Gdynia 2018.

Kurowski L., Wstęp do nauki prawa finansowego, Warszawa 1976.

Kurzępa E., Stany nadzwyczajne w polskim porządku prawnym, Warszawa 2017.

Miemiec M., Stany nadzwyczajne (stan wojenny, stan wyjątkowy, stan klęski żywiołowej) w Konstytucji Rzeczypospolitej Polskiej, Przegląd Prawa i Administracji 2016, t. 106.

Nalepa T., Modelowe rozwiązania $w$ zakresie finansowania zadań utrzymywania mocy produkcyjnych i remontowych, niezbędnych do realizacji prac wynikajacych z PMG, Wiedza Obronna 2011, nr 2.

Nalepa T., Nakładanie zadań wynikających z programu mobilizacji gospodarki na przedsiębiorców o szczególnym znaczeniu gospodarczo-obronnym, Wiedza Obronna 2013, nr 4.

Nawrot M.M., Rola programu mobilizacji gospodarki oraz systemu rezerw państwowych w przygotowaniach obronnych państwa, Zeszyt Problemowy TWO 2011, nr 1.

Owsiak S., Finanse publiczne. Teoria i praktyka, Warszawa 2005.

Prokop K., Stany nadzwyczajne w Konstytucji Rzeczypospolitej Polskiej, Białystok 2005.

Steinborn S., w: Konstytucja RP, t. 2. Komentarz do art. 87-243, red. M. Safjan, L. Bosek, 2016 [baza danych Legalis].

Stepaniuk K.M., Zagadnienie zmian $w$ wydatkach budżetu państwa $w$ trakcie jego realizacji $w$ świetle ustawy o finansach publicznych, w: Finanse publiczne, red. A. Pomorska, Lublin 2006.

Szczurowski B., w: Konstytucja RP, t. 2. Komentarz do art. 87-243, red. M. Safjan, L. Bosek, 2016 [baza danych Legalis].

Szmulik B., Szymanek J., O możliwości wprowadzenia stanu nadzwyczajnego w kontekście epidemii koronawirusa, Przegląd Legislacyjny 2020, t. 27, nr 1.

Zubik M., Budżet państwa w polskim prawie konstytucyjnym, Warszawa 2001. 
